\title{
A Preface to the Islamic Personality Psychology
}

\author{
Nooraini Othman ${ }^{1}$ \\ ${ }^{1}$ UTM Perdana School, Universiti Teknologi Malaysia, Jalan Semarak, Kuala Lumpur, Malaysia \\ Correspondence: Nooraini Othman, UTM Perdana School, Universiti Teknologi Malaysia, Jalan Semarak, 54100 \\ Kuala Lumpur, Malaysia. Tel: 60-321-80-5157. E-mail: p-noraini@utm.my
}

Received: August 7, 2015 Accepted: November 13, 2015 Online Published: December 17, 2015

doi:10.5539/ijps.v8n1p20 URL: http://dx.doi.org/10.5539/ijps.v8n1p20

\begin{abstract}
The personality psychology of Islam stands as an essential feature in the understanding of Islamic psychology. Human being, being physical and metaphysical in nature is certainly a complex creature. It is physical as it involves the study of human being and his personality and metaphysical as it is studying the unseen matters of the person such as his heart, mind, spirit and soul. The study of psychology is a scientific domain that deals with behaviour of a person. Thus, this paper briefly analysed the concept of personality in Islam, the Islamic worldview and its relationship with personality and finally Islamic personality psychology.
\end{abstract}

Keywords: Islamic personality, Islamic personality psychology, Islamic psychology

\section{Introduction}

Personality is one of the areas of psychology that holistically looks at a person as an individual and a complex creature. Scientific analysis carried out on personality theory evolves around questions such as why we are where we are now? In responding to the question, we cannot run away from facing the truth that human behaviour is indeed complex. Humans may have many similarities and yet be different in so many respects. Much research has revealed that researchers attempted to establish the meaningful relationship between personality and various aspects of human behaviour. These include but are not limited to, Freud (1938), Allport (1961), Adler (1964), Bandura (1977) and Rogers (1980).

The definition of personality, as given by Hergenhahn and Olson (1999), explains that personality allows someone to be more effective socially as he is seen as possessing an attractive personality or else in the absence of such a personality, the person may be seen as bad or has no personality at all. When personality is associated with its root word persona which means mask, it reflects the aspects of the self to be portrayed to, and seen by, the world. This definition also suggests that there are important aspects of an individual that he/she conceals for his/her own reason and does not intend to share them with the world.

One's personality is seen to be unique and special so that it differentiates him from another person. Such an aspect is called individual difference. Researches on personality gave birth to numerous personality theories that have helped us in understanding and analyzing various aspects of human personality.

\section{Personality in Islam}

Personality in Islam carries different meanings. Islam referred to as ad-deen in Islamic terminology means the complete way of life. It is a system of thought and action. According to Abu Al-'Ala al-Maududi' (1984), Islam explains the relationship between God and man, and man and man. It prescribes a moral code, enunciates the principles of culture and civilisation, lays down the mode of worship and establishes a framework of belief as well as defining the moral imperatives which must govern the life of Muslims. These rules include social and cultural relationships, economic, judicial, and political dealings, matters of war and peace, and international affairs. God does not leave man without guidance. He sent down a messenger who was accompanied by the revealed book of God, namely the Quran.

The mission of the Messenger (Rasulullah), did not end with the announcement of the message. He guided the people by explaining to them the implications of the Islamic creed, the moral code, the Divine injunctions and commandments, and the form of worship that sustains the whole system.

Hammudah 'Abdalati (1984) defines Islam as designating submission to the good, benevolent will of God, and obedience to His law. This definition captures the essence of Islam, which is a deep, profound internal 
commitment of the individual Muslim. This internal commitment is, however, valid only when it is supported by external manifestations, by actual fulfilment of duty, and by dynamic interest in that to which one is committed. Here, faith and action join together to integrate the personality of the individual and make his life meaningful. Clearly, there is no viable faith without some purposeful action to reinforce it, nor can there be any meaningful action of perpetual significance without faith.

One should not forget that the mission of Prophet Muhammad has to be understood in the following manner. Firstly, being what has been said by Allah as prescribed in the Quran and secondly, being what the prophet personally proclaimed. As regards the first point, Allah says in the Quran (Al-Anbia', p. 107), "I (Allah) do not send you (being Messenger) except as blessings to the world".

As for the second point, the prophet said, to the effect that: "Verily I was made a Messenger to perfect the conduct of mankind".

Ansari (2001) states that the mission of a Muslim is to build up his own personality, his social environment and the world in general. For this purpose, he has to equip himself to reach possible heights of perfection in respect of, and to cooperate with others in the pursuit of all that is healthy and constructive human activities.

The only purpose was to strengthen the personality of the people so that the world of beauty and perfection may be illuminated before their eyes and they may try to achieve it consciously and with knowledge. The importance are shown in all the Islamic compulsory forms of worship which are designed as exercises and training to enable people to acquire correct morals and habits and to live righteously, and also to adhere to these virtues until the end, whatever the changes in their circumstances (Muhammad, 1994). In the author's view, the human personality is at the core of their activities.

\section{Islamic Worldview and Personality}

Acikgenc (1996) defines a worldview as the ultimate foundation of all human conduct, including scientific, philosophical and technological activities. The mental framework is the totality of the concepts and the mental attitude developed by the individual throughout his life, and as such it constitutes what we call "worldview". Since the worldview is taken to be the basic foundation of any action, it can be concluded from this that every human action is ultimately traceable to its worldview; and as such it is reducible ultimately to that worldview. Al-Attas (2001) explained Islamic worldview as follows:

".....the worldview of Islam encompasses both al-dunya and al-akhirah, in which the dunya-aspect must be related in a profound and inseparable way to the akhirah-aspect, in which the akhirah-aspect has ultimate and final significance. The dunya-aspect is seen as a separation to the akhirah-aspect. Everything in Islam is ultimately focused on the akhirah-aspect without thereby implying any attitude of neglect or being unmindful of the dunya-aspect".

Both, al-dunya and al-akhirah are two concepts that explain the worldview of Islam in an interesting manner. Al-dunya means the present world where as al-akhirah means the world hereafter. In the belief system of Islam (Tawhid), the life and human deeds in the present world will have a significant impact in the life in the world hereafter. If one is obedient to the command of God and virtous in the present world, that person's life will be bountiful and blessed in the hereafter.

The Islamic view is that life must be guided by the principle of Tawhid (Al-Faruqi, 1992). It is the testimony that Allah is the one and only God worthy of worship and that Prophet Muhammad is the Messenger of Allah. It means that total obedience to the commands of Allah and adherence to the teachings of the Prophet would set a criteria par excellence in the life of a Muslim. He further explained that al-Tawhid is a general view of reality, of truth, of the world, of space and time, of human history and destiny. At the core of religious experience stands God.

The shahadah is confession of Islamic faith; witnessing that there is no god but God (Allah) and Muhammad is His Messenger. "The God", occupies the central position in every Muslim place, every Muslim action, every Muslim thought. The presence of God fills the Muslim's consciousness at all times. With the Muslim, God is indeed a sublime obsession. Sometimes a whole culture, a whole civilisation, or a whole history lies compressed in one sentence. This certainly is the case for al-Shahadah. All the diversity, wealth and history, culture and learning, wisdom and civilisation of Islam is compressed into the shortest of sentences, coupled with a testimony. This is an oath of allegiance, faithfulness and obedience to the commands - the do's and the don'ts-of the Messenger of Allah. He plays the role of guiding the people on to the path of Allah and the attainment of His pleasure. In the Quran (An-Nahl, p. 36), Allah says: “Unto each and every community we have sent a Messenger 
to teach them to serve none but Allah and to avoid evil'.

The author, in her past work (Khairul 'Azmi \& Nooraini, 2004), stated that the essence of Tawhid is to take the very words of Allah as revealed in the Quran and the message of the Prophet as contained in the hadith, as the guiding lights and principles of life. The challenge, however, is to translate them into every sphere of the Muslim life. The changing reality of the world would certainly provide enough challenge to fulfil the task. No matter how complex life would be, the dynamics of Islamic teachings would always be relevant. Such dynamism emerges in response to the dynamics of the changing circumstances. The teaching of Islam has never been rigid nor obsolete. If there is one, it is an individual person who chooses to live in a rigid way.

According to Malik Bennabi (2002), in his discussion about man and religion, religion is an independent force underlying the existence of human society and determining human culture and civilisation. In fact, he strongly argues that religion is at the origin of all historical societies and thus has been an inexhaustible source of moral ideals and values for human life. Bennabi was first and foremost concerned with how to reconstruct Muslim society, revive its culture and purge it of the negative elements inherited from its age of decline as well as from the deformities it suffered under western colonialism. Human society needs progress, but it has to be in a comprehensive sense encompassing the spiritual, moral, mental and material dimensions.

It is the advent of religion whose germ is sown deep in the structure and history of human kind, as well as in the cosmic order of existence. Besides providing the foundation of an ethos that develops along side the societal evolution and cultural development of human groups, religion assumes the function of a catalyst that effects the fundamental synthesis of human society and civilisation. Accordingly, it is the spiritual relationship between God and man that creates and determines the social bonds which link every individual with his fellow humans. It is religion that ultimately gives birth to the social relationship in the form of moral values and thus it naturally inscribes itself in the origin of all human transformations.

In all accounts, as Bennabi has argued, human beings do organise themselves as a society that generates culture and establishes civilisation only when they subscribe to a divine revelation which provides them with "a law and way of life", thus endowing their existence with meaning and direction. Any attempt at cultural reconstruction and civilisational renaissance of a society, such as Muslim society, has to take stock of the historical dynamics that governed its march in time and space. Both intellectual elites and social and political movements need to be aware of the psycho-historical conditions which were at the origin of its birth and emergence as well as of the forces which participated in the shaping and determination of its character and working in the different phases of its history. A society can successfully achieve reconstruction and rebirth only if it succeeds in reviving its original master ideas and ideals in such a way as to meet the demands and challenges of new circumstances. This, according to Bennabi, is a universal law which governs the rise and fall of societies and civilisations.

History has invariably taught us that the rise and fall of civilisations has been chiefly due to the citizenry. It is the people that make up civilisations. It is the quality of the citizens that is the most important ingredient to effect dramatic change to society and nations. Islam, for example nurtured its earliest community based on truth and justice such that within a short span of time it had spread its influence throughout Arabia, Central Asia, North Africa and even South Eastern Europe. It was also Islamic civilisation that made a tremendous contribution to the various fields of knowledge. This was because of the deliberate and concerted efforts undertaken by the early Muslims to integrate both the physical and spiritual aspects of life in all spheres.

Religion has a very pertinent role to play. Religion should never be regarded as simply rituals which affect people only at an individual level. Religion which seeks truth to establish justice in all aspects of societal life should be regarded as beneficial to society. It is religion which acts as the anchor or underlying principles that govern not only the physical and material well-being but also the spiritual growth and upliftment of man. It is religion that steers people towards a more balanced life. It is also religion that provides true guidance and the strongest motivation towards achieving a more fruitful and meaningful life.

The issue at hand is to find the ways and means of how a nation can produce society that has at its core the deep sense of religious consciousness, committed to the highest standards of ethical and moral values and yet is industrious, dynamic and dedicated towards advancement and progress. This is indeed very necessary and pertinent because we can easily achieve material progress by physical planning. But, the stark truth is that all the material wealth that we have accumulated can be completely wiped out if we do not have the morally right values among the people who manage them. We have repeatedly seen this happen at the individual and family levels; we have also read in history about the fall of empires for the same reason. And we are seeing today the destruction of many civilisations.

Secondly, we have to be conscious of the need for balanced and integrated development in the sense that its 
planning should incorporate the need for spiritual uplifting right from the start and not to leave such a vital thing to the end. We have so far completely ignored this aspect of development, especially during the initial planning stage, and if we include them it is only as an afterthought.

Thirdly, it is essential to realise that in the past we have concentrated almost entirely on physical development. Of late we have been incorporating some aspects of human development mainly in the form of non-spiritual human resource development. What is most pertinent is that there is a great difference between human resource development and human development. The former involves matching of the demand for different categories and skill levels of manpower with the supply so that there is not an acute mismatch in terms of numbers as well as categories and skills. Human development entails the kind of education, training and environment that is necessary to develop all the potentials of the human individual in both body and soul, which is, his dual nature. This aspect of development has not been given sufficient attention, and so it is no surprise, therefore, that we are faced with numerous human problems.

The Quran (Ar-Rum:41) reminds us:

"Mischief has appeared on land and sea because of (the need) that the hands of men have earned. That (Allah) may give them a taste of some of their deeds: in order that they may turn back (from evil)".

It can be learnt here that humans are completely responsible for all the mischief that has appeared on this earth. This mischief is the result of our own proclivity for evil. Therefore, human personality development based on the teaching of Islam has to be at the centre of the civilisational construct.

\section{Islamic Personality Psychology}

Personality is the manifestation of our character in everything we do in life (Abdul, 2005). Moral character is thus not simply a goal within the life of a Muslim, but the end goal of the Islamic faith itself. On this matter, Prophet Muhammad was asked, "Which Muslim has the perfect faith?" He answered: "He who has the best moral character". Human personality in the Islamic tradition is understood through the total make up of body, mind and soul. To understand the overall psychological nature of man and his personality development, one must understand the inner workings or the essence, of the whole person.

The study of human personality will not be complete without understanding the factors which influence its development. According to Najati (1968a), any research on biological, social and cultural factors without including the study of the spiritual aspect, will only lead to a vague description and shallow understanding about personality. The study on basic concepts of human nature and its potentialities will lead the way in understanding human personality.

Raba (2001) was of the view that human nature is the bedrock for the development of human personality. The focus of his study was to unravel the impact of human nature as an underlying factor that brings about different personality types. The Holy Quran points out that man was created for a special purpose, hence he is equipped with faith as well as the necessary knowledge and potential that can enable him to accomplish his mission on earth as a servant of Allah. Faith and belief in Allah, the capacity to learn, to do good and otherwise, to bear responsibility, to love, to acquire wealth and power, are inherent in his duties on earth.

Man has a dual nature of body and soul (Al-Attas, 1990). According to Hasan Langgulung (2002), man is composed of clay, which belongs to the world of creation and is subject to motion, change and alteration, bound by time and space. The ruh (soul), which belongs to the world of command, is free and not limited by these two binding factors. Man is composed of body and spirit. Spirit is transcendent and is the centre of man's being. Soul is attached to the body in its downward tendency and to the spirit in its upward or spiritual tendency.

According to the Quran, all psychological phenomena originate in the self. The self is the essence of man, and is often referred to by one of four Arabic terms; qalb (heart), ruh (soul), nafs (desire-nature) and 'aql (intellect/reason) (Al-Ghazali, 1988). Each one signifies spiritual entities. Islamic scholars typically highlight the three most commonly referred to states of the self in the Quran as:

1) Nafs Ammarah (The lower self)-This self is prone to the lower aspects of the self, representing the negative drives in man. It can be viewed as the Freudian concept of id. In other words, it is the animalistic level of the self.

2) Nafs Lawammah (The self-reproaching self) — corresponds to the self when it becomes aware of wrongdoing.

3) Nafs Mutmainnah (The peaceful self) — the state of inner peace and happiness, content with that which Allah is pleased with. 
The Qalb, as Al-Ghazzali calls it, is the essence of man. It is the spiritual entity which abides in his physical body and controls his organic and psychical functions (Umaruddin, 2003). It is connected with the physical heart, therefore it is called Qalb (heart) even though the connection is merely transcendental. In other words, the physical heart is the form while the spiritual heart is the substance.

Fitrah is associated with being born as a Muslim when viewed in terms of shahadah.

As stated in the Quranic verse, Ar-Rum 30:30:

"Set your face to the Deen in sincerity which is Allah's fitrah upon which He created mankind. There is no changing the creation of Allah. That is the right Deen but most people know not".

Imam An-Nawawi defined fitrah as the unconscious state which exists until the individual consciously acknowledges his belief.

Yasien (1996) explains although man is born in a state of fitrah, he also has the potential to commit wrongdoing, kufr (rejection of tawhid) and breaking the divine law. These are all part of the Divine scheme of Creation. Allah has endowed man with the inborn capacity to distinguish right from wrong through intellect, free will and revelation. Although man is not born evil, he is vulnerable to evil stimuli or external sources of misguidance. This property of the human constitution is intrinsic to man and is referred to as the psyche or the self (nafs) of man.

Man stands midway between animals and angels and his unique characteristic is intelligence $(a q l)$. He can rise to the level of the angels with the help of the intellect or stoop to the level of the animals by permitting his anger and lust to dominate him. Allah has created all bodily organs and faculties of the self to help man realize his fitrah. However, Al-Ghazali emphasized that the realisation of fitrah can be achieved only when the intellect has been fully applied. A prerequisite for the application of the intellect is through knowledge.

Najati (1968a) explained about the existence of the conflict between animal and angelic characters in the human personality. Both are competing with one another in fulfilling their needs. Allah said in the Quran (An-Nazi'aat, pp. 37-41),

"Then for him who transgressed all bounds (in disbelief, oppression and evil deeds of disobedience to Allah). And preferred the life of this world (by following his evil desires and lusts), verily, his abode will be Hell-fire. But for him who feared standing before his Lord, and restrained himself from impure evil desires and lusts. Verily, Paradise will be his abode".

Najati explained further that this conflict is a test from Allah for the human. Nik Mustafa (1994) explained that the animalistic elements provide the energy for changes to take place, and the angelic elements are to ensure changes are in realm of human nobility. Those who are able to balance the needs derived from these aspects are those who belongs to the successful people and will be rewarded in this world and the hereafter.

In contrast to the Freudian concept of human development, the Islamic view may be described as psycho-spiritual. Both psychic and spiritual dimensions are recognised. The link between nafs and ruh becomes manifest in terms of the relationship they share. Another secular dimension of Freud's theory is his concept of the human organism as tending, in terms of the law of conservation of energy, towards homoeostasis. The psychoanalytic parallel to this scientific principle of physics is known as thanatos - the death instinct. There is an unconscious desire within the individual to maintain a metabolic equilibrium by opposing the life instinct (eros) in order to achieve a state of rest in death. Crudely put, every human being has an unconscious wish to die.

Sheikh Abdullah Faisal (1997) made an interesting analysis which is contradict to the Freudian concept of thanatos. According to him, human was endowed with numerous and various instincts and one of it is the survival instinct. This instinct refers to love for life and strong fear of old age and death. This instinct was given to us by Allah so that we would avoid committing suicide. Therefore whenever a person commits suicide, this behaviour of his or hers is considered abnormal. Thus, it should be understood that human beings are given birth in order to live.

Man is a special creation due to the spark of Allah's Spirit that makes him unique apart from the rest of creation. Allah said in the Quran (Al-Hijr, p. 29):

"So, when I have fashioned him completely and breathed into him (Adam) the soul which I created for him, then fall (you) down prostrating yourselves unto him".

The Islamic personality, grounded in high moral character, encompass beliefs, external traits, attributes, behaviour, manners and social graces, and $a d a b$ (Abdul, 2005). It covers every aspect of interpersonal life, including relations between man and man, man and God, man and family, man and society, as well as man and 
the natural world. All of these are clearly reflected in the life stories of the Prophet, and are thoroughly documented in his seerah (prophetic life journal).

The Islamic personality is a clear and distinct personality. Its fabric is the Book of Allah, and its thread is the Sunnah, and these two are inseparable from it. It is a sincere and determined personality educated and refined upon a precise methodology which does not contain even the slightest deficiency, and how could it since it is the Religion of Allah (Shaikh 'Alee Hasan, 1995).

It is clearly stated in the Quran (Ar-Rum, p. 22) on the existence of individual differences based on genetic and environmental changes.

"And among His Signs is the creation of the heavens and the earth, and the difference of your languages and colours. Verily, in that are indeed signs for men of sound knowledge".

According to Najati (1968a; 1968b), the related verses and hadiths show that the differences among humans cover the physical aspects including the skin colour, shape and size as well as their potentials and emotions. Thus, the varieties in human body structure play a role in shaping the personality, especially from emotional aspects. The Prophet himself stated that genetic and environmental factors play their own specific role in creating individual differences.

Islamic personality psychology can be described as characteristics or traits of human behaviour which is being translated from the human thinking process. It takes into account the dimensions of human nature that is 5 elements of self (body, heart, mind, spirit and soul) and how these elements interacted with one another to form and influence the thinking and behaviour of a human. Traits and characteristics are the products potrayed by the Muslims in form of their behaviour. These behaviours are the outcome of their understanding towards the Islamic spiritual and physical creation of human as being conceptualised in the teaching of Islam (Nooraini, 2008; 2011a). The concept of Ilm, Iman and Ihsan are applicable in this context (Nooraini, 2011b).

\section{Conclusion}

Islam urges its followers to have a good personality and has underlined certain principles and guidance to Muslims which is promoted by the Prophet as a role model. Human morality can be defined as confirming to the rules of right conduct. There exist a strong belief that moral decline cannot be avoided when the nation develops and prospers. The thesis is that there is an inverse relationship between a country's modernisation and moral decay among its people. Many are even convinced that upholding morality will hinder economic performance and ultimately country's development. This is based on the assumption that by adhering to the high moral standards prescribed by religion, productivity among the workforce will deteriorate. Thus, to achieve rapid development, a nation has to compromise by accepting declining morality (Nik Mustafa, 1994). It is further explained by Nik Mustafa that the decline of morality in western societies is basically due to their world views on the nature of man and the position of material affluence.

Hasan Langgulung (1985) stated that psychologists believe that human behaviour relates to their needs in life, while at the same time they face the challenge of organising the competing needs. In the modern society, their needs are not as modest as the primitive society as each need will eventually produce another set of needs to the extent of infinity, even though it may lead to destruction of the self and the society. This is in line with the pleasure principle that eventually corrupts other aspects of life, including values, culture, politics, economics, society, science and religion. In Islam, it is stated that man by nature requires freedom to decide his own future and he needs to socialise with others to improve himself. Despite personal interest, man also has social responsibilities to ensure that every single member is able to satisfy all his basic needs. High morality thus is a prerequisite to achieve this united approach by all individuals to advance a nation's progress and prosperity. Islam recognises the importance of morality, and indeed one of the missions of the Prophet of God was to establish high morality among men (Nik Mustafa, 1994).

When referring to Islamic personality, it means the total development and balanced growth of human personality (Hasan Langgulung, 1991). The spiritual dimension of people has to be restored to its proper place to be able to claim the totality of a person's personality. Thus, Hasan Langgulung (1991) suggested that the physical aspect, a psychological component and a spiritual aspect, be actualised as a model of personality development. The development of total personality, therefore, will mean the development of Insan Kamil or perfect man or woman.

It is the pusuit of Insan Kamil that one has to vie for. It is an ideal personality and holistic in nature. A correct understanding of the concept of personality in Islam will lead Muslims to learn on how to develop their personality (Nooraini \& Khairul, 2014). With that they can function efficiently and play their role properly, beneficial and fit for the modern world. A future work on comparative analysis between the Islamic personality 
psychology and the western counterpart will be useful to understand the subject matter further.

\section{References}

Abdul, L. A. (2005). Towards the concept of Islamic personality. Retrieved November 23, 2005. http://www.crescentlife.com/articles/islamic\%20psyc/concept_of_islamic_personality.htm

Al-Faruqi, I. R. (1992). Al-Tawhid: Its implications for thought and life. Virginia: International Institute of Islamic Thought.

Acikgenc, A. (1996). Islamic Science: Towards a definition. Kuala Lumpur: International Institute of Islamic Thought and Civilisation.

Adler, A. (1964). Social interest. A challenge to mankind. New York: Capricon.

Al-Attas, S. M. N. (1990). The nature of man and the psychology of the human soul. Kuala Lumpur: International Institute of Islamic Thought and Civilisation.

Al-Attas, S. M. N. (2001). Prolegomena to the metaphysics of Islam. Kuala Lumpur: International Institute of Islamic Thought and Civilisation.

Allport, G. W. (1961). Pattern and growth in personality. New York: Holt, Rinehart and Winston.

Ansari, M. F.-u.-R. (2001). The quranic foundations and structure of Muslim Society (Vol. 1). Kuala Lumpur: Islamic Book Trust.

Bandura, A. (1977). Social Learning Theory. Englewood Cliffs, NJ: Prentice Hall.

Bennabi, M. (2001). The Quranic phenomenon: An essay of a theory on the Quran. Kuala Lumpur: Islamic Book Trust.

Freud, S. (1938). The basic writings of Sigmund Freud. In A. Brill (Ed.). New York: The Modern Library.

Hammudah 'Abdalati. (1984). Islamic social system: Its dimensions and characteristics. In M. Tariq Quraishi (Ed.), Islam: A way of life and movement. Indiana: American Trust Publications.

Hasan, L. (1985). Konsep ilmu menurut Al-Ghazali. Journal Pendidikan Islam, 3, 1-11.

Hasan, L. (1991). Integrated personality and integrated education: A psycho-spiritual approach. Muslim Education Quarterly, 8(4), 32-43.

Hergenhahn, B. R., \& Olson, M. H. (1999). An introduction to theories of personality. New Jersey: Prentice Hall.

Muhammad, A.-G. (1994). Muslim's Character. Pakistan: Darul Ishaat.

Najati, M. U. (1968a). Al-hadith an-nabawi wa 'ilmu an-nafs. Mesir: Darus Syuruk.

Najati, M. U. (1968b). Al-Quran wa 'ilmu an-nafs. Mesir: Darus Syuruk.

Nik, M. N. H. (1994). The relevance of human centred development in the industrial era. IKIM Journal, 2(1), 79-92.

Nooraini, O. (2008). The Development and Validation of the Ummatic Personality Inventory. Skudai: Penerbit UTM.

Nooraini, O. (2011a). Exploring the Ummatic Personality Inventory Dimensions from the Psycho-Spiritual Paradigm. International Journal of Psychological Studies, 3(2). http://dx.doi.org/10.5539/ijps.v3n2p37

Nooraini, O. (2011b). Explorasi Dimensi Ummatic Personality Inventory (UPI) Sebagai Alat Pengukuran Personaliti Psiko-Spiritualiti Islami. In Ulum Islamiyyah (Vol. 7). Penerbit Universiti Sains Islam Malaysia.

Nooraini, O., \& Khairul, A. M. (2014). Integrated System in the Malaysian Education Paradigm: A Catalyst for a Holistic Personality Development. International Education Studies, $7(5)$. http://dx.doi.org/10.5539/ies.v7n5p8

Raba, A. M. (2001). Major personalities in the Quran. Kuala Lumpur: A. S. Noordeen.

Rogers, C. R. (1980). A way of being. Boston: Houghton Mifflin.

Shaikh 'Alee Hasan 'Alee 'Abdul Hameed. (1995). The Islamic personality. United Social and Behavioural Sciences. Lanham: Rowman \& Littlefield Publishers, Sons Ltd.

Sheikh, A. F. (1997). Natural instincts (Islamic psychology). London: Darul Islam Publishers 1td.

Umaruddin, M. (2003). The ethical philosophy of Al-Ghazzali. Kuala Lumpur: A. S. Noordeen. 
Yasien, M. (1996). Fitra: The Islamic concept of human nature. London: TaHa Publishers Ltd.

\section{Copyrights}

Copyright for this article is retained by the author(s), with first publication rights granted to the journal.

This is an open-access article distributed under the terms and conditions of the Creative Commons Attribution license (http://creativecommons.org/licenses/by/3.0/). 